\title{
PELATIHAN PENDIDIKAN KESEHATAN REPRODUKSI DALAM RANGKA PENINGKATAN PENGETAHUAN DAN SIKAP MAHASISWA SMAN 1 SUKAMARA
}

\author{
${ }^{1}$ Jenny Oktarina \\ ${ }^{1}$ STIKes Borneo Cendekia Medika \\ ${ }^{1}$ Email : oktarina.jenny@yahoo.co.id
}

\begin{abstract}
ABSTRAK
Kehidupan remaja merupakan kehidupan yang sangat menentukan bagi kehidupan masa depan mereka selanjutnya. Pada tahun 2010 jumlah remaja usia 10-19 tahun di Indonesia sebesar 43.548.576 jiwa atau 18,33 \% dari total jumlah penduduk Indonesia yang mencapai 237.641.326 jiwa. Hal ini berarti bahwa seperlima penduduk indonesia adalah remaja berusia 10-19 tahun (Badan Pusat Statistik, 2010). Melihat jumlahnya yang sangat besar, remaja juga mempunyai permasalahan yang kompleks seiring dengan masa transisi yang dialami remaja. Masalah yang perlu mendapatkan perhatian khusus seperti masalah perilaku seks pranikah, NAPZA (Narkotika, Psikotropika dan Zat Adiktif) dan HIV/AIDS (Wahyuni dan Rahmadewi, 2011). World Health Organization (WHO) memperlihatkan bahwa semakin meningkat pula aktivitas seksual di antara kaum muda di kawasan AsiaPasifik. Hasil RISKESDAS tahun 2010 diketahui bahwa Indonesia termasuk negara dengan persentase pernikahan. Metode tanya jawab dan ceramah, digunakan pada saat pemberian pendidikan kesehatn reproduksi. Metode demonstrasi dan latihan, digunakan pada saat menyampaikan materi konsuling.

Evaluasi hasil praktik konseling menggunakan pedoman evaluasi yang sudah disiapkan sebelumnya. Hasil kegiatan pengabdian pada masyarakat ini dapat disimpulkan baik. Hal ini dibuktikan dari hasil praktik peserta. Berdasarkan hasil evaluasi praktik, para peserta dapat melakukan konseling dengan baik. Pada pelatihan ini melakukan pendidikan kesehatan reproduksi yang diaplikasikan dalam bentuk konseling teman sebaya. Hal ini dilakukan dengan tujuan mengetahui kemampuan para peserta melakukan konseling sebagai bentuk evaluasi dilakukan semua peserta untuk mengukur kemampuan sebelumnya belum pernah dipraktikan sama sekali. Kegiatan pengabdian kepada masyarakat ini dapat dijadikan sebagai sarana untuk meningkatkan keterampilan, pengembangan kreativitas, dan menambah wawasan serta pengetahuan tentang kesehatan reproduksi serta kemampuan dalam melakukan konseling sebaya. Konseling sebaya diyakini dapat menjadi salah satu cara mengatasi masalah remaja yang kompleks. Setelah pelatihan berakhir diharapkan peserta yang telah memperoleh pengetahuan kesehatan reproduksi dan keterampilan konseling sebaya dapat mentransfer pengetahuan dan mempraktekkan ilmu yang sudah didapat sehingga bermanfaat buat teman sebaya.
\end{abstract}

\section{Kata Kunci : Pendidikan, Kesehatan Reproduksi, Pengetahuan, Sikap}

\section{ABSTRACT}

The life of a teenager is life that very much determined for life their future next. In the year 2010 the number of teenagers age 10-19 years in indonesia is about 43.548 .576 people or $18,33 \%$ of all 237.641 .326 soul indonesian population has reached. This means that a fifth of the population are teenagers the dependants aged 1019 (the central bureau of statistics, 2010 ). See they were so many very large, teenagers also have a complex problem in line with the transition to what happened to the teenager. Problems that need to get special attention as 
behavior problems premarital sex, 000 (narcotic, psychotropic and the addictive substances) and hiv / aids so wahyuni rahmadewi and, 2011. World health organization (who) revealed that the lower the increased as well sexual activity among young people in asia pacific region. The results of riskesdas 2010 known that indonesia including the states with the percentage of marriage. A method of a question and answer session and lectures, in use at the time the provision of education healing reproduction. A method of demonstrations and exercise, given the lectures konsuling in use at the time.

The results of the evaluation practices counseling use evaluation guidelines prepared before. The outcome of the activities, and community good this it can be concluded. This is proven participants from the results of the practices. Based on the evaluation of practices, the participants will do well counseling. Carried out at training the reproductive health education applied in the form of counseling their peers. This is achieved by objective of knowing the ability of participant counseling as a form of the evaluation is done all participants to measure the aptitude previously not been practice at all. Activities devotion to these communities can be used as a means of increasing skill, the development of creativity, and their well as knowledge on the reproductive health and ability to do counseling age .Counseling age is believed to be been one way to overcome the problem of teen who was complex.After training ends it is expected that participants who have acquiring knowledge and reproductive health skill counseling age be able to transfer knowledge and practice the science which have been obtained so that possible for their peers.

Keyword: education, reproductive health, knowledge, attitude

\section{Pendahuluan}

Kehidupan remaja merupakan kehidupan yang sangat menentukan bagi kehidupan masa depan mereka selanjutnya. Pada tahun 2010 jumlah remaja usia 10-19 tahun di Indonesia sebesar 43.548.576 jiwa atau 18,33\% dari total jumlah penduduk Indonesia yang mencapai 237.641.326 jiwa. Hal ini berarti bahwa seperlima penduduk indonesia adalah remaja berusia 10-19 tahun (Badan Pusat Statistik, 2010).

Melihat jumlahnya yang sangat besar, remaja juga mempunyai permasalahan yang kompleks seiring dengan masa transisi yang dialami remaja. Masalah yang perlu mendapatkan perhatian khusus seperti masalah perilaku seks pranikah, NAPZA (Narkotika, Psikotropika dan Zat Adiktif) dan HIV/AIDS (Wahyuni dan Rahmadewi, 2011).

Perilaku seksual pranikah di kalangan remaja diperkuat dengan data dari Depkes Tahun 2009 di 4 kota besar (Medan, Jakarta Pusat, Bandung dan Surabaya), menunjukkan bahwa $35,9 \%$ remaja mempunyai teman yang sudah pernah melakukan hubungan seks pranikah dan 6,9\% responden telah melakukan hubungan seks pranikah (Depkes RI, 2009). World Health Organization (WHO) memperlihatkan bahwa semakin meningkat pula aktivitas seksual di antara kaum muda di kawasan AsiaPasifik. Hasil RISKESDAS tahun 2010 diketahui bahwa Indonesia termasuk negara dengan persentase pernikahan usia muda tinggi di dunia (ranking 37) (Kementerian Kesehatan, 2009).

Perilaku seksual remaja memiliki kecenderungan sikap yang permisif pada remaja terhadap perilaku seks bebas atau perilaku seks di luar nikah. Sikap permisif remaja terhadap perilaku seks bebas didukung oleh terbatasnya pengetahuan remaja tentang kesehatan reproduksi remaja (Luthfie R.E, 2008). Survei Dasar Kesehatan Reproduksi Republik Indonesia (SDKRI) di Kota Manado 
tahun 2000 menunjukkan pengetahuan dasar yang dimiliki responden mengenai kesehatan reproduksi relatif terbatas. Keadaan ini dapat diketahui dari $57,78 \%$ responden tidak mengetahui pengertian seksualitas. Pengetahuan remaja tentang kesehatan reproduksi sangat rendah yaitu sekitar $75 \%$. Rendahnya pengetahuan remaja tersebut berdampak pada perilaku seksual remaja menuju ke arah yang sangat membahayakan atau ke perilaku seksual yang berisiko (Aryani, 2010).

Menanggapi permasalahan tersebut Pusat Informasi dan Konseling Remaja (PIK-R) (Badan Kependudukan Keluarga Berencana Nasional, 2008). BKKBN mengembangkan program kelompok umur sebaya. Berdasarkan hasil laporan dari BKKBN jumlah PIK-R yang telah terbentuk di Indonesia, adalah sebanyak 2.773 PIK-R yang didirikan di sekolah- sekolah sebanyak $55 \%$, di Lembaga Swadaya Masayarakat (LSM) $15 \%$ dan 35\% yang didirikan di Karang Taruna (Siswanto, 2008). Keberadaan dan peranan Pendidik Sebaya di lingkungan remaja sangat penting artinya sebagai narasumber kesehatan reproduksi remaja (KRR) bagi teman sebayanya. Keterampilan yang didapatkan melalui pelatihan dapat untuk meningkatkan ketrampilan dalam berkomunikasi dan meningkatkankan kepercayaan kepada teman sebayanya yang membutuhkan pemenuhan keingintahuan mengenai KRR.

Menurut data SMAN 1 Sukamara jumlah siswi yang dikeluarkan dari sekolah akibat hamil diluar nikah adalah sebagai berikut pada tahun 2013 jumlah siswi yang dikeluarkan adalah 2 siswi, pada tahun 2014 tidak ada siswi yang dikeluarkan karena hamil diluar nikah, pada tahun 2015 jumlah siswi yang dikeluarkan adalah 1 siswi. Pada tahun 2016 jumlah siswi yang dikeluarkan adalah 3 siswi. Dari data tersebut jumlah siswi yang dikeluarkan mengalami peningkatan dari tahun 2017 ke tahun 2018.

Dengan adanya peranan dari pusat informasi konseling remaja di berbagai setiap wilayah diharapkan mampu memberikan dan mensosialisasikan permasalahan berkaitan seputar Seksualitas, HIV, AIDS dan NAPZA sehingga menekan jumlah besarnya permasalahan yang dihadapi remaja setiap tahunnya.

\section{Metode}

Untuk memecahkan permasalahan yang dihadapi dalam pelatihan ini, maka dipilih beberapa metode pemecahan sebagai berikut :

Metode tanya jawab dan ceramah, digunakan pada saat pemberian pendidikan kesehatn reproduksi

Metode demonstrasi dan latihan, digunakan pada saat menyampaikan materi konsuling.

Evaluasi hasil praktik konseling menggunakan pedoman evaluasi yang sudah disiapkan sebelumnya.

\section{Hasil}

Hasil kegiatan pengabdian pada masyarakat ini dapat disimpulkan baik. Hal ini dibuktikan dari hasil praktik peserta. Berdasarkan hasil evaluasi praktik, para peserta dapat melakukan konseling dengan baik. 
Evaluasi hasil praktek meliputi :

1. Banyaknya yang bertanya,

2. Hasil pre dan post test

3. Pemecahan masalah dalam menyelesaikan sebuah kasus

\section{Pembahasan}

Pada pelatihan ini melakukan pendidikan kesehatan reproduksi yang diaplikasikan dalam bentuk konseling teman sebaya. Hal ini dilakukan dengan tujuan mengetahui kemampuan para peserta melakukan konseling sebagai bentuk evaluasi dilakukan semua peserta untuk mengukur kemampuan sebelumnya belum pernah dipraktikan sama sekali.

Berdasarkan evaluasi hasil praktik untuk pendidikan kesehatan reproduksi diperoleh hasil sebagai berikut :

1. Banyaknya yang bertanya, setelah pembicara selesai menyampaikan materi dan dibuka sesi pertanyaan hampir dari $50 \%$ peserta ingin bertanyaan, ini menunjukkan bahwa antusias siswa sangat tinggi.

2. Hasil pre dan post test, setelah dilakukan pre dan post test maka didapatkan hasil yang menunjukkan bahwa ada peningkatan pengetahuan.

3. Pemecahan masalah dalam menyelesaikan sebuah kasus. Setelah sesi penyampaian materi selesai maka dilanjutkan yang namanya sesi konseling sebaya yang dimana dirancang seperti drama dan diberi beberapa kasus.

4. Hasil Akhir dari kegiatan ini siswa dapat melakukan konseling kepada teman sebaya dengan melakukan berbagai macam pendekata yang sudah didapat dari materi khususnya yang berhubungan dengan kesehatan reproduksi.

\section{Kesimpulan dan Saran Kesimpulan}

Kegiatan pengabdian kepada masyarakat yang telah dilakukan ini banyak memberikan manfaat terutama dalam meningkatkan pengetahuan, sikap, serta keterampilan dalam melakukan konseling kepada sebaya. Selain itu kegiatan pengabdian kepada masyarakat ini dapat dijadikan sebagai sarana untuk meningkatkan keterampilan, pengembangan kreativitas, dan menambah wawasan serta pengetahuan tentang kesehatan reproduksi serta kemampuan dalam melakukan konseling sebaya. Konseling sebaya diyakini dapat menjadi salah satu cara

mengatasi masalah remaja yang kompleks.

\section{Saran}

Setelah pelatihan berakhir diharapkan peserta yang telah memperoleh pengetahuan kesehatan reproduksi dan keterampilan konseling sebaya dapat mentransfer pengetahuan dan mempraktekkan ilmu yang sudah didapat sehingga bermanfaat buat teman sebaya.

\section{Daftar Pustaka}

Badan Pusat Statistik., 2013. Proyeksi Penduduk Indonesia. Jakarta: BPS.

Badan Pusat Statistik., 2010. Penduduk Indonesia Menurut Provinsi dan Kabupaten/Kota Sensus Penduduk 2010. Jakarta: BPS. 
Badan Pusat Statistik., 2013. Survei Demografi dan Kesehatan Indonesia 2012, Jakarta.

Irianto, K., 2014. Pelayanan Keluarga Berencana Dua Anak Cukup. Bandung: Alfabeta.

Setyorini, A., 2014. Kesehatan Reproduksi \& Pelayanan Keluarga Berencana. Bogor: In Media.

KEMENKES., 2015. Profil Kesehatan Indonesia 2014. Jakarta: Kementerian Kesehatan RI

Badan Pusat Statistik., 2008. Survei Demografi dan Kesehatan Indonesia 2007, Jakarta.

Saifuddin, A., 2012. Buku Panduan Praktis Pelayanan Kontrasepsi. Jakarta: Yayasan Bina Pustaka Sarwono Prawirohardjo.

KEMENKES., 2013. Situasi Keluarga Berencana di Indonesia. Buletin Jendela Data dan Informasi kesehatan. Vol.2, Semester 2, 2013.

Asih, L \& Oesman, H., 2009. Analisa Lanjut SDKI 2007 Faktor Yang Mempengaruhi Pemakaian Kontrasepsi Jangka Panjang (MKJP). Jakarta: Penerbit KB dan Kesehatan Reproduksi, BKKBN

KEMENKES., 2013. Riset Kesehatan Dasar 2013. Jakarta: Kementerian Kesehatan RI 